\title{
Introduction of Culture into English Teaching
}

\author{
Guo Xiuzhen \\ Foreign Language School \\ North China Institute of Science and Technology \\ Yanjiao, China \\ Guoxiuzhen1982@163.com
}

\begin{abstract}
As language and culture are interrelated, language cannot go without culture. So, it is necessary to introduce culture to English teaching. This paper mainly analyses the major reasons for introducing culture to English teaching and how culture teaching can be conducted into English classroom and teacher's roles in culture teaching. It is concluded that the introduction of culture to English teaching is necessary, so that the effect of English teaching can be improved and smooth intercultural communication can be achieved.
\end{abstract}

\section{Keywords- culture; English teaching; teaching methods}

\section{INTRODUCTION}

The world is getting smaller and smaller. Improvement in transportation technology, developments in communication technology and globalization of the economy have made intercultural communication more necessary than ever, but cultural difference is always the obstacle to smooth communication. For example, what does "green with envy" mean in English? Dose it really mean that when a person is envious, his or her face becomes green? Another example, In English there is "Paul was in blue mood." Here what does "blue" mean? In fact, in the two examples, neither "green" nor "blue" refers to color. In the first one "green" modifies envy to express the degree of envy. In the latter one, "blue" means "gloomy or unhappy", having nothing to do with color "blue". Without culture background we can hardly get the real meaning of "green" and "blue". The third example, if a Chinese says, "where are you going?" which is a kind of greeting in China to a native English speaker, the English speaker would be annoyed and probably reply with "It's none of your business!” Obviously, this misunderstanding is also caused by cultural differences. So, it is clear that the introduction of culture to English teaching is important and necessary. Owe to the importance and the necessity, this paper gives a brief introduction of culture teaching in high school English class and gives some suggestions on methods of culture teaching. I hope that these suggestions can give some help to teachers and improve the efficiency of English teaching.

\section{MAJOR ReAsons FOR CUlture TEACHING IN ENGLISH CLASSROOM}

\section{A. Language and Culture \\ What does "culture" mean? Samovar and Porter define it as "the cumulative deposit of knowledge, experience,}

\author{
Wang Mei \\ Foreign Language School \\ North China Institute of Science and Technology \\ Yanjiao, China \\ Hello8659@163.com
}

beliefs, values, attitudes, meanings, hierarchies, religion, notions of time, roles, spatial relations, concepts of the universe, and material objects and possessions acquired by a group of people in the course of generations through individual and group striving". "language" is defined by some linguists as "a system of arbitrary vocal symbols used for human communication”(Hu, 1987).

The relationship between language and culture is dialectic. On the one hand, every language is part of a culture. It serves and reflects culture needs. For example, Eskimo has a rich vocabulary for different kinds of snow whereas English has only two. The fact that Eskimo boasts a large number of snow terms has a ready explanation in the important part snow plays in the life of the Eskimos(Hu, 1987) . On the other hand, culture influences language. For example, in English a sharper awareness of women's need for independence has given currency to such term as "chairperson" and "spokesperson”, and has helped to make the use of "their" in sentences like "Every one has to do their job properly" more acceptable, in preference to the male chauvinistic "his" and the clumsy "his or her" $(\mathrm{Hu}$, 1987). So, if a person wants to learn a language well, he or she should learn the culture background related to the language.

The purpose of learning a foreign language is to use it as a tool to communicate with other nations, which makes the introduction of culture to language teaching important. In China, the introduction of culture to English teaching starts from the 1980s. One of its characteristics is that it is closely connected with China's modernization process and opening up and reform. The process of modernization speeds up the exchange of products and thoughts with other foreign countries. The world is becoming smaller and smaller and even becoming a "global village". So, intercultural communication between different nations becomes a necessary part in people's life. However, cultural difference is the main impediment to intercultural communication. If one enterprise wants its products to enter international market or a transnational company wants to make benefits in many counties and regions, what they need is not only high technology and smart managing but also the knowledge of different cultures. For example, in China "dragon" is the symbol of luck and power. Chinese feel proud as descendents of dragon. However, in western people do not have special feelings to dragon and even regard dragon as an ugly and threatening monster. If one company does not have this knowledge and puts their 
products printed with dragon into international market, there is no doubt this company will fail to stimulate western people to buy their products. From this point of view, it is very necessary to learn culture while learning English.

\section{B. Situation of Culture Teaching in China}

In china, the strong force driving students to study English is to pass entrance examinations for high schools and colleges. So, in most high schools the grammartranslation is still the most dominant method in English teaching. This method is grammar oriented, which means that teachers only emphasize the grammar and sentence structures in English teaching and ignore the introduction of cultural background of English-speaking countries. This way of teaching leads to the situations where most students, even those who have entered universities, have not attained a high level of English proficiency. A complaint by a native English teacher may provide us with a suggestion. She says, “They (students) depend on me to do everything. In most classes, they just sit there and I have to tell them to talk..." Her students probably are enthusiastic and eager to learn English, but the fact that the teacher and her students belong to different cultures affects their teaching and learning negatively. This situation of English teaching in China worries many linguists. They insist that culture should be taught in English teaching, so that the situation can be changed and English teaching can go effectively.

\section{Methods of Culture TeAChing IN EngLish Class}

Based on my experience of learning English and the books I have read on culture teaching and English teaching, I have got some ideas about how to teach culture in English classroom and what kind of roles English teachers should play in the teaching. The ideas are only a small part of the whole culture teaching, but I hope they can help to make the teaching of culture a better experience for both teachers and students.

There are many books that introduce methods of culture teaching. Some linguists state eighteen successful methods of culture teaching. I combine the methods I have got on books and my experience of learning English and then acquire two methods that I think are effective. One is the combination of language and culture; the other is the method of discussing.

\section{A. Combination of Culture and Language}

This method supplies brief explanations or a guidance of culture implications. It is important to combine language and culture especially in vocabulary teaching. This is because some words have different connotations from culture to culture. For example, the words to describe energetic can be taken differently. Two years ago, I realized how the word "active" has a different connotation in Canada and in China. In China, "active" is in most cases a compliment, such as, in class if a student often answers questions voluntarily, then teachers can take he or she as "active". Therefore, I did not hesitate to say "You are active" to my male teacher who is Canadian when he was teaching us play a lot of games in class. The result of my words is that he was slightly embarrassed because "active" means "sexually active" in Canada. Fortunately, this incident is trivial. It is far better not to offend people. If I know this general difference I can avoid this to some extent.

Some languages have huge vocabularies in certain areas. For example, American has several words corresponding to "drunk" namely, "pissed", "pickled", "high”, "bombed”, “stoned”, "intoxicated”. This is because cars are very common in America and driving after drinking probably causes big damage.

Proverbs and sayings carry cultural connotations and meanings, too. One Chinese proverb goes "Silence is gold" meaning that silence is better or useful than eloquence. On the other hand, English proverb says "Squeaking wheels get oil" which means if you are quiet, you cannot receive anything. As we have seen, silence has different connotations in the U.S and China.

All these examples provide us with a suggestion that English teachers should pay attention to the combination of culture and language and introduce culture to vocabulary teaching and text explanations in English class.

\section{B. Method of Discussing}

Discussion is probably one of the most different activities for Chinese students. In every day life, Chinese seldom discuss or argue. Once an argument starts, it can be serious and emotional. Although discussion is valuable in teaching culture, we cannot expect all students to be able to discuss complex issues at high level in foreign language. Often, even high-level students need some preparatory activities with clear goals before they can proceed to discussion. Here are some favorite activities:

(1) Quiz

Many teachers have found that quiz is one of the more successful activities. It can be used to test materials that teachers have previously taught, but it is also useful in learning new information. For example, look the simple true or false quiz about Ireland below.

With a partner, answer true or false to the following questions:

A: There is little snow except in the mountains in Ireland. Kong.

B: The population of Ireland is less than that of Hong Ireland.

C: The United Kingdom includes the Republic of

$\mathrm{D}$ : Ireland is totally dark during the winter.

Teachers should ask the students to answer true or false to each of the questions in pairs or groups. They will share their existing knowledge and common sense to give answers. It is not important whether students get the right answer or not, but by predicting, students will become more interested in finding out the right answer. At this point, extra information can be provided. Teachers can also ask students to quiz their partner about reading or other materials. Quizzing offers a high-interest activity that keeps students involved and learning.

(2) Reformulation 
When students have read an activity or listened to a story, teachers may like to use reformulation to allow them to check what they have learned and to reinforce it by retelling it to their partners. Reformulation simply means: "Explain what you just learned to your partner in your own words.” It is a very simple technique, but has proved very successful for learning both culture and language. Through reformulation, students check what they have learned, find out things that they have missed from their partners, and improve their language by noticing gaps in their own ability to explain.

\section{(3) Noticing}

As students watch a video or are engaged with some other materials, teachers can ask them to "notice" particular features. For example, they could watch a video of a targetculture wedding and note all the differences with their own culture and then discuss. Asking students to "notice" gives a focus on the materials by making it into task, rather than simply passive viewing or listening.

(4) Prediction

Prediction can be a useful tool in quizzes, but it can also be equally useful in using almost any materials. Like "noticing", prediction can engage the students more actively. For example, when teacher is telling a story, he or she can stop at a certain point and ask students to predict how it will continue. Or, when a teacher is giving out a reading for homework, first gives the title of the reading and asks students to predict what they will learn and discuss with their partners. This will force them to review their existing knowledge of the topic and raise their curiosity about whether their prediction is correct or not.

\section{(5) Research}

Student research is one of the most powerful tools that teachers can use with college students, because it combines their interests with the English class. For example, after the first class, teachers can ask students to search the Internet or library and find information on any aspects of the targetculture that interests them. In the following class, students explain to their group what they have learned and answer any questions about it. This can lead to poster-sessions or longer projects. For some students, it can even lead to a long-term interest in the target-culture.

\section{Teacher's Roles in Culture Teaching}

Can teacher's attitudes towards students and culture learning in English class depend on each teacher? It goes without saying that every teacher has his or her own personality, aptitude and philosophy about English education. It is also true that teachers should be informed and trained linguistically and cross-culturally. Without formal instructions, teachers will end up depending upon their intuitions, previous knowledge and experiences.

What should teachers do to have students appreciate different cultures and expand their horizons without risking their identity and without oversimplifying or over generalizing their ideas towards different cultures? Teachers should help students to realize that they can find their own third position between two cultures, their native and second culture. Then students will be objective to both cultures. In order to convince students of this idea, teachers need to give sufficient information about cultures. A Japanese linguist suggests the concept of third position. Teachers should teach students form their identity as the third position, so that they can accept that each culture has its own norms and standards and they do not judge these norms and standards from their native culture standpoints. Their standpoints are between their own culture and the second culture, therefore they can be less biased and prejudiced to both cultures.

Teachers themselves also ought to learn culture differences that interfere with smooth communication. Without knowing the differences, they are not fully able to give information to their students. They do not need to have experiences overseas, however, they are required to be good communicators among people from different cultures. It can be suggested that English teachers-to-be might what to have culture studies in the course of teacher training. Currently in China culture learning is not compulsory for future teachers. So some current and future teachers may not know cultural differences between China and English speaking countries. If teachers do not know cultural differences that interfere with communication, are they less competent than those who have the knowledge? The answer is partly yes and partly no. As recent textbooks in China are inclined to select global issues such as starvation in Africa or Brazilian rain forest, teachers are bound to teach historical and cultural background no matter whether they have learned the cultural differences or not. However, teachers who have the knowledge of cultures can provide extra systematic description and analysis that may grab students' attention. In addition, teachers with formal culture learning experiences know what to teach, what to inform students. Therefore, future teachers have to learn different cultures in a formal setting.

\section{CONCLUSION}

Earlier in this paper, we have seen that language and culture are inseparable. So it is important to learn culture while learning a language. Considering English and Chinese are two different language systems, introducing different cultures and cultural tolerance is necessary so that learners can expand their horizons and come to accept differences. Negative feeling towards different groups will be reduced and more smooth communication will be achieved. In culture teaching, teacher plays an important role, which does not mean that students can entirely depend on teachers to learn culture in English class. Students themselves should also cultivate their interests in culture learning. In this way, the introduction of culture can really be effective and properly help to improve the effect of English teaching.

\section{ACKNOWLEDGMENT}

This article is sponsored by the fundamental research funds for the Central Universities of China(WY1205B). Special thanks go to my teacher Song Yan in Shandong University of Science and Technology. 


\section{REFERENCES}

[1] Brown, H.D. Principles of Language Learning and Teaching. New Jersey: Prentice-Hall, 1980, pp. 50-55.

[2] Hu Zhuanglin, Liu Renqing, Li Yanfu. Linguistics. Beijing: Beijing University Press, 1987, pp. 50-57.

[3] Kawano, M. 'Teaching Culture in English Class in Japan.' http:// www.ntu.edu.cn, 2000.

[4] Kramsch, C. Context and Culture in Language Teaching. London: Oxford, 1994, pp.73-78.

[5] Samovar, L.A. \& Porter, R.E. Communication Between Cultures. California: Wadsworth, 1995, pp.10-14.

[6] Stern, H.H. Issues \& Options in Language Teaching. London: Oxford, 1996, pp. 12-20. 